Reuben Lasker (1930-1988).

Reuben Lasker died on Saturday. March 12. of the complictions of cancer after a long and courageous struggle. He was 58 . His pioneering work in fisheries and biological oceanography has been an inspiration to his students and colleagues and will be the best testimonial to his memory.

Reuben is survived by his wife. Caroline; two grown children, a daughter Pamela Lasker-Smith of Santa Barbara, California, and a son, Paul Lasker of Los Angeles, California; and by his father. Theodore J. Lasker of San Diego.

We plan a joint Scripps Institution of Oceanography-National Marine Fisheries Service memorial service in the near future. We hope also to set up the Reuben Lasker Memorial Fund with the income from this fund used to facilitate the attendance of students to the annual CalCOFI meeting, one of Reuben's abiding interests. Contributions can be sent in care of the Reuben Lasker Memorial Fund, P.O. Box 271, La Jolla, California 92038. For further information. please call Li1lian Vlymen at (619) 546-7070.

Contributed by Ladore Barrett. Science and Research Director. Southwest Region. National Marine Fisheries Service

Paul M. Fye (1913-1988).

Paul M. Fye died on Friday, March 11, 1988, at home at age 75. Dr. Fye was the fourth Director of the Woods Hole Oceanographic Institution, serving nineteen years from 1958-1977. In 1961 he was also elected President of the Corporation, a post he held until 1986.

He believed that the future of marine science as well as of mankind lay in cooperation not only among scientists but among nations. "Research is an activity that flourishes only if it is freely permitted to determine its own priorities," he said of the need for nations to unite in the pursuit of knowledge about the oceans. "Nature knows no political boundaries and ocean phenomena do not stop at the continental shelf."

His dreams of bringing together people involved in the social, economic, and political aspects of our use of the oceans was realized in 1970 with the establishment of the Marine Policy and Ocean Management Program at Woods Hole Oceanographic Institution. Policy Associates and Fellows from many nations came together to study and work at the Institution, and the program has assisted developing nations to plan for the wise use of their marine resources. He served as Director of the program during its first ten years and again as Acting Director in 1985-1986. He served in an advisory capacity in recent years, working every day until his death.

He leaves his wife, Ruth E. Heym Fye of Falmouth, a son, Dr. Kenneth P. Fye of Boston and a daughter Elizabeth R. Murphy of Norwood; and three step-grandchildren.

Contributed by Woods Hole Oceanographic Institution Information Services

\title{
THE OCEANOGRAPHY GRAdUATE COUNCIL AT TEXAS A\&M UNIVERSITY
}

\author{
By Ann Jochens and Greg Smith. \\ Department of Oceanography. Texas A\&M University. \\ College Station, TX 77843
}

\begin{abstract}
Editor's Note: This section of the magazine will be used to discuss the interests and concerns of graduate students in oceanography and related fields. The first contribution, from students at Texas A\&M University, calls for the formation of a national organization of oceanography graduate students. We solicit and welcome concise descriptions of the activities, interests, and concerns of oceanography students at other institutions.
\end{abstract}

$\mathrm{T}$ he Oceanography Graduate Council (OGC) of Texas A\&M University in College Station, Texas, is a student organization designed to enhance the educational environment of graduate students and to foster quality interactions with the faculty. The OGC, which presently has about 85 members, provides an effective mechanism for students to offer opinions about issues of concern, such as computer usage and the selection of seminar speakers. The OGC also provides an excellent environment for the development of leadership capabilities.

The OGC sends new and prospective students information about the community, housing. the University, and the Department. A welcoming party for new students is sponsored each fall at a faculty member's home. Through fund raising activities such as paper recycling. monies are obtained to fund a mini-grant program, which provides monetary assistance to enable students to attend conferences. to present papers and poster sessions, and for unfunded research activities.

Each semester, the OGC solicits student reviews of all the courses offered by the department and furnishes the results to students, faculty, and administrators. The OGC publishes a newsletter twice a semester which reports to students, fac- ulty and staff on topics of academic and recreational interest. The OGC contributes money for purchase of books for the Working Collection (a marine science library located in the Oceanography building). Parties and "happy hours" sponsored by the OGC help the students relax after work and provide a positive social setting for interaction with faculty.

We believe that students should have a voice in the development of The Oceanography Society (TOS). Such a voice will encourage TOS to address issues of particular interest to graduate students. In return. students can assist with TOS activites and offer insights from the students' perspective. To accomplish this, we propose the formation of a national Council of Oceanography Graduate Students (COGS), comprised of representatives from member institutions and governed by an elected executive committee. The principal functions of COGS would be to promote student oceanography organizations, provide a forum for development of student views, and promote student interest and awareness in the professional world of oceanographers. If COGS prospers, the Executive Council of TOS could be petitioned to include the COGS president as a voting member. The COGS should meet to conduct its business at the annual TOS spring meeting, beginning in the spring of 1989.

To promote an exchange of ideas and provide information to students, a bulletin board named GRAD.STUDENTS has been established on Telemail/Omnet. The bulletin board provides a convenient way to discuss matters of student concern. Suggestions and ideas about COGS are especially welcomed.

Persons interested in further information can contact Ann Jochens through the bulletin board or at Texas A\&M University, Department of Oceanography, College Station, Texas 77843. 